\title{
Greener synthesis and DNA photocleavage activity of 1, 5-Diaryl-3-trifluoromethylpyrazole derivatives: ${ }^{\dagger}$
}

\author{
Girish Kumar Gupta 1,*, Vinod Kumar ${ }^{2}$ and Vipin Saini ${ }^{3}$ \\ 1 Department of Pharmaceutical Chemistry, M M College of Pharmacy, Maharishi Markandeshwar \\ University, Mullana-133207, Ambala, Haryana, India; girish_pharmacist92@rediffmail.com \\ 2 Department of Chemistry, Maharishi Markandeshwar University, Mullana-133207, Ambala, Haryana, \\ India; vinodbatan@gmail.com \\ 3 Vice-Chancellor, Maharishi Markandeshwar University, Solan, Himachal Pradesh, India; \\ vipinsaini31@rediffmail.com \\ * Correspondence: girish_pharmacist92@rediffmail.com; Tel.: +91-805-993-0169 \\ + Presented at the title, place, and date. \\ Academic Editor: name \\ Received: date; Accepted: date; Published: date
}

Abstract: 1,5-Diaryl-3-trifluoromethypyrazole derivatives have acquired much attention in the past few years due to their good biological potential. In the present communication, some 1,5-diaryl-3-trifluoromethylpyrazoles were synthesized by one-pot solid phase reaction. The DNA photocleavage study of the synthesized compoundswas performed using agarose gel electrophoresis method. To have better insight of how our ligands interacted with the DNA, molecular docking simulations through Autodock Vina were also performed. All the compounds have shown good binding with the DNA. It has been found that pyrazoles containing phenyl rings at both positions ( 1 and 5) possessing electron releasing as well as electron withdrawing groups enhance the DNA photocleavage potential. As the synthesized derivatives shown the promising DNA photocleavage activity, so they may serve the basis of some bioactive heterocycles in the future.

Keywords: Trifluoromethypyrazole; Computational study; DNA photocleavage activity

\section{Introduction}

Pyrazole and its derivatives are well known for their excellent biological properties [1-4]. In view of the importance of pyrazole nucleus, recently several synthetic routes have been reported in the literature. However, regardless of their potential synthetic utility, many of the reported methodologies suffer from certain drawbacks like harsh reaction conditions, complex product isolation procedures, application of hazardous organic solvents etc. [5, 6]. Therefore, the development of cost effective and eco-friendly chemical protocols for the preparation of biologically important heterocycles constitutes a major challenge for chemists in organic synthesis. 


\section{Materials and Methods}

\subsection{Synthesis of 1,5-diaryl-3-trifluoromethylpyrazoles (3a-l)}

Most of the common chemicals used in the present study were purchased from commercial suppliers and were used without further purification. Melting points were taken on LabIndia visual melting range apparatus and are reported as such. ${ }^{1} \mathrm{H}$ NMR and ${ }^{13} \mathrm{C}$ NMR spectra were taken on Bruker Nuclear Magnetic Resonance (NMR) spectrometer instrument of $300 \mathrm{MHz}$ and $75 \mathrm{MHz}$, using tetramethylsilane (TMS) as an internal standard in $\mathrm{CDCl}_{3}$. However, $\beta$-diketones bearing trifluoromethyl 1 and aryl hyrazines 2 were prepared according to the well known procedure [7-9]. Compounds 1 ( $\beta$-diketones bearing trifluoromethyl) $(1 \mathrm{mmol})$, arylhydrazines 2 (1 mmol) and p-toluenesulphonic acid $(2.5 \mathrm{mmol})$ were ground vigorously in a mortar using pestle. The contents were then transferred into a $250 \mathrm{ml}$ conical flask and heated to about $50^{\circ} \mathrm{C}$ for $10-20 \mathrm{~min}$. A yellow colored solid thus obtained was washed with water, filtered, dried and recrystallized from ethanol.

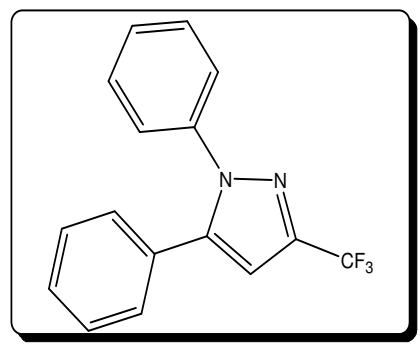

(3a)
Yield: $68 \%$;

m.p. $80^{\circ} \mathrm{C}$ (Lit. m.p. $79^{\circ} \mathrm{C}$ );

${ }^{1} \mathrm{H}$ NMR $\left(\mathrm{CDCl}_{3}, 300 \mathrm{MHz}\right): \delta=6.75(\mathrm{~s}, 1 \mathrm{H}$, 4-H), 7.23-7.34 (m, 10 H, Ph'-H \& Ph"-H)

Figure 1 1,5-Diphenyl-3-trifluoromethylpyrazole

\subsection{DNA Photocleavage activity}

DNA photocleavage experiment was performed by taking $10 \mu \mathrm{l}$ solution of PBR322 DNA in TE (Tris $10 \mathrm{mM}$, EDTA $0.01 \mathrm{mM}, \mathrm{pH} 8.0$ ) buffer along with $40 \mu \mathrm{g}$ of synthesized compounds. The sample solutions held in caps of polyethylene microcentrifuge tubes were placed directly on the surface of a trans-illuminator $(8000 \mathrm{~m} \mathrm{~W} / \mathrm{cm})$ at $360 \mathrm{~nm}$ and were irradiated for $30 \mathrm{~min}$ at room temperature. After UV-irradiation, samples were further incubated at $37^{\circ} \mathrm{C}$ for $1 \mathrm{hr}$. Irradiated samples were then mixed with 6x loading dye constituted from $0.25 \%$ bromophenol blue and $30 \%$ glycerol. The samples were then analyzed by electrophoresis on a $0.8 \%$ agarose horizontal slab gel in Tris-Acetate EDTA buffer (40 mM Tris, $20 \mathrm{mM}$ acetic acid, $1 \mathrm{mM}$ EDTA, pH: 8.0). Untreated plasmid DNA was maintained as a control in each run of gel electrophoresis which was carried out at $5 \mathrm{~V} / \mathrm{cm}$ for $2 \mathrm{hr}$. Gel was stained with ethidium bromide $(1 \mu \mathrm{g} / \mathrm{ml})$ and photographed under UV light [10]

\subsection{Docking studies}

Molecular docking is a computational method to generate and score the probable protein-ligand complexes calculated on the basis of binding affinities. This technique is successfully used for discriminating compounds on the basis of their ability to fit in the binding sites of the protein $[11,12]$. The co-crystal complex structure of aB-DNA Dodecamer (PDB ID: 1BNA) was employed for the molecular docking studies. 
The molecular docking simulations in case of 1,5-diaryl-3-trifluoromethylpyrazoles (3a-1) were performed using AutodockVina [13]. Autodock tools of Molecular Graphic Laboratory (MGL) were employed to generate the complete pdbqt files of receptor of ligands and receptors. Receptor generation and optimization was done in the following steps: (i) addition of polar hydrogens to the receptors, (ii) removing the water of crystallization from the complex, (iii) computaion of the Gasteiger Charges, and (iv) location of the grid box (Discovery Studio was employed to identify the coordinates of the centre of internal ligand in the binding site). The site of the Grid Box is given in Table 1. For the ligand files, PDB files drawn in Marvin sketch of Chemaxon were loaded in Autodock tools and converted to pdbqt files.

For initiating the molecular docking in AutodockVina, one configuration file is prepared which contain the information about the position of receptor file, ligand, coordinates of grid box and the size of the grid box which was set to $30 \times 30 \times 30$ points.

Table 1. Position of the GRID box center in the protein molecule

\begin{tabular}{cccc}
\hline PDB code & \multicolumn{3}{c}{$\mathrm{X}, \mathrm{Y}, \mathrm{Z}$ coordination $(\AA)$} \\
\hline & $\mathrm{X}$ & $\mathrm{Y}$ & $\mathrm{Z}$ \\
1BNA & 5.7 & -3.8 & 29.8 \\
\hline
\end{tabular}

\section{Results and Discussion}

\subsection{Chemistry}

Viewing a wide range of pharmaceutical activities of pyrazole and its derivatives, it was decided to synthesize some 1,5-diaryl-3-trifluoromethyl substitution based pyrazoles for biological interest. In the present communication, we disclosed the p-TSA (para-toluene sulphonic acid) mediated synthesis of 1, 5-diaryl and 3-trifluoromethyl based pyrazoles from the reaction of 1,3-dicarbonyl compounds with different hydrazines. General method for the synthesis of 1,5-diaryl-3-trifluoromethylpyrazoles (3a-1) is outlined in Figure 2, Table 2, which was accomplished by a grinding technique.

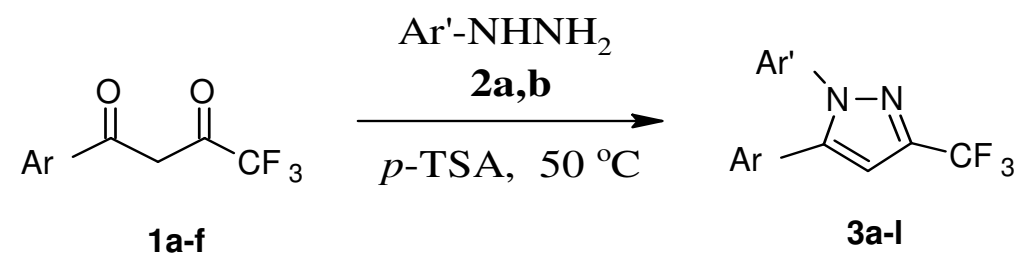

Figure 2 General method for synthesis of 1,5-diaryl-3-trifluoromethylpyrazoles (3a-1) 
Table 2 1,5-diaryl-3-trifluoromethylpyrazole derivatives (3a-1)

\begin{tabular}{cccccc}
\hline Compound & $\mathbf{A r}$ & $\mathbf{A r}^{\mathbf{\prime}}$ & Compound & $\mathbf{A r}$ & $\mathbf{A r}^{\mathbf{\prime}}$ \\
\hline $\mathbf{3 a}$ & $\mathrm{C}_{6} \mathrm{H}_{5}$ & $\mathrm{C}_{6} \mathrm{H}_{5}$ & $3 \mathbf{g}$ & $\mathrm{C}_{6} \mathrm{H}_{5}$ & $4-\mathrm{NO}_{2} \mathrm{C}_{6} \mathrm{H}_{4}$ \\
$3 \mathbf{b}$ & $4-\mathrm{OCH}_{3} \mathrm{C}_{6} \mathrm{H}_{4}$ & $\mathrm{C}_{6} \mathrm{H}_{5}$ & $\mathbf{3 h}$ & $4-\mathrm{NO}_{2} \mathrm{C}_{6} \mathrm{H}_{4}$ & $4-\mathrm{NO}_{2} \mathrm{C}_{6} \mathrm{H}_{4}$ \\
$3 \mathbf{c}$ & $4-\mathrm{NO}_{2} \mathrm{C}_{6} \mathrm{H}_{4}$ & $\mathrm{C}_{6} \mathrm{H}_{5}$ & $3 \mathbf{i}$ & $4-\mathrm{BrC}_{6} \mathrm{H}_{4}$ & $4-\mathrm{NO}_{2} \mathrm{C}_{6} \mathrm{H}_{4}$ \\
$\mathbf{3} \mathbf{d}$ & $4-\mathrm{BrC}_{6} \mathrm{H}_{4}$ & $\mathrm{C}_{6} \mathrm{H}_{5}$ & $\mathbf{3 j}$ & $4-\mathrm{ClC}_{6} \mathrm{H}_{4}$ & $4-\mathrm{NO}_{2} \mathrm{C}_{6} \mathrm{H}_{4}$ \\
$3 \mathbf{e}$ & $4-\mathrm{ClC}_{6} \mathrm{H}_{4}$ & $\mathrm{C}_{6} \mathrm{H}_{5}$ & $\mathbf{3 k}$ & $4-\mathrm{OCH}_{3} \mathrm{C}_{6} \mathrm{H}_{4}$ & $4-\mathrm{NO}_{2} \mathrm{C}_{6} \mathrm{H}_{4}$ \\
$\mathbf{3 f}$ & $4-\mathrm{FC}_{6} \mathrm{H}_{4}$ & $\mathrm{C}_{6} \mathrm{H}_{5}$ & $\mathbf{3 1}$ & $4-\mathrm{FC}_{6} \mathrm{H}_{4}$ & $4-\mathrm{NO}_{2} \mathrm{C}_{6} \mathrm{H}_{4}$ \\
\hline
\end{tabular}

It has been observed that condensation of $\beta$-diketones with hydrazines in the presence of $p$-TSA furnish the desired product rapidly (within 10-20 min). The known products were characterized by comparing their melting points with those reported in the literature [14]. A sharp singlet near $\delta 6.8$ in ${ }^{1} \mathrm{H}$ NMR spectra confirms the formation of pyrazole nucleus. Furthermore, A sharp signal in ${ }^{19} \mathrm{~F}$ NMR spectrum at $\delta-62.9 \mathrm{ppm}$ also provides a firm evidence in support of the structure of 1,5-diaryl-3-triflouromethylpyrazoles (3a-1).

\subsection{DNA Photocleavage study}

The DNA photocleavage study of the synthesized compounds (3a-j) was performed using agarose gel electrophoresis method and results are presented in Figure 3. The decrease in the intensity of plasmid DNA in case of compounds 3a-j in (Lane 1-10) as compared to control (Lane C) indicated the cleavage of DNA forms. Further, pyrazoles containing phenyl rings at both positions (1 and 5) possessing electron releasing as well as electron donating groups enhance the DNA photocleavage potential.

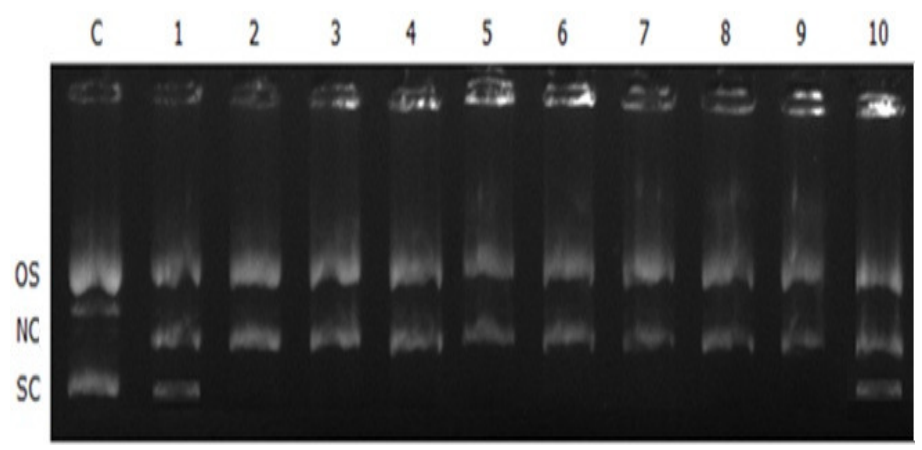

Figure 3 DNA Photocleavage study of 1,5-Diaryl-3-trifluoromethypyrazoles (3a-j) Lane C: Control plasmid

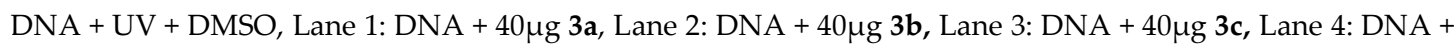

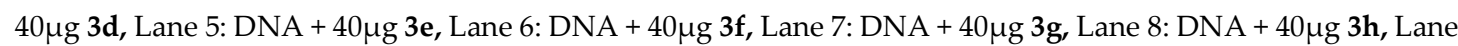

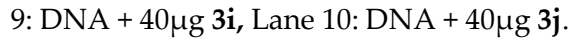

\subsection{Docking study}

With an aim to achieve some more support to our proposition and to find some indepth relationship with experimental in vitro DNA photcleavage activity, a versatile docking method was developed by using software Autodock Vina. All the compounds have shown good binding with the DNA, showing the binding energy in between -7.0 to $-8.0 \mathrm{KJ} / \mathrm{mol}$. The binding pose of one derivative $3 \mathbf{a}$ with the DNA molecule is presented in the Figure 4. 


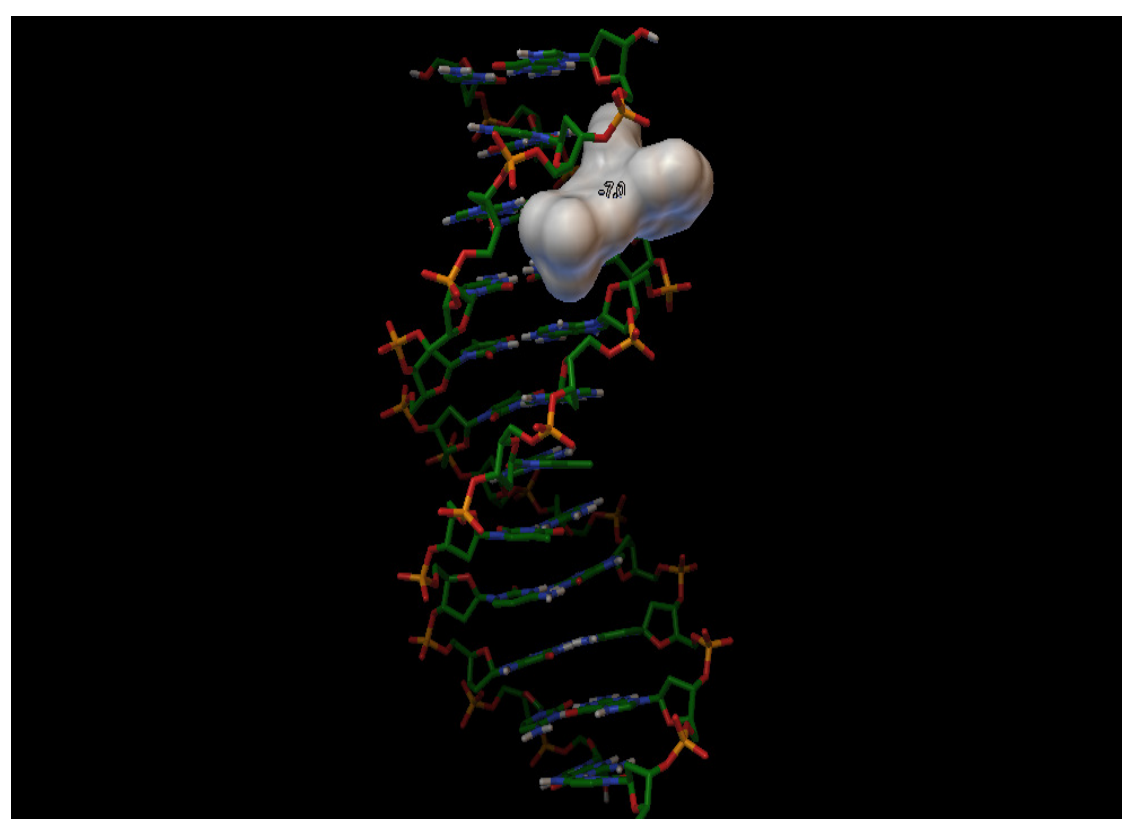

Figure 4 Molecular docked model of compound 3a with DNA [dodecamer duplex of sequence d(CGCGAATTCGCG)2 (PDB ID: 1BNA)]

\section{Conclusion}

The present methodology overcomes the formation of unwanted isomeric byproducts, low yields, high temperature, and dry solvents. All the compounds have shown the promising DNA photocleavage activity and thus may serve the basis of some bioactive heterocycles in the future.

Acknowledgments: The support and facility from Maharishi Markandeshwar University, Mullana, Ambala, Haryana, India for conduct of this work is gratefully acknowledged.

Author Contributions: Vinod Kumar and Girish Kumar Gupta conceived and designed the experiments; Girish Kumar Gupta performed the experiments; Vinod Kumar and Girish Kumar Gupta analyzed the data; Vipin Saini contributed reagents/materials/analysis tools; Girish Kumar Gupta wrote the paper.

Conflicts of Interest: The authors declare no conflict of interest.

\section{References}

1. Gupta, G.K.; Kumar, V.; Kumar, V. Pyrazoles as potential anti-obesity agents: A review, Res. J. Chem. Environ. 2011, 15, 90-103.

2. Kumar, V.; Kaur, K.; Gupta, G.K.; Gupta, A.K.; Kumar, S. Developments in synthesis of the anti-inflammatory drug, Celecoxib: A review, Recent Pat. Inflammation Allergy Drug Discovery 2013, 7, 124-134. https://doi.org/10.2174/1872213X11307020004

3. Kumar, V.; Kaur, K.; Gupta, G.K.; Sharma, A.K. Pyrazole containing natural products: Synthetic preview and biological significance (A Review), Eur. J. Med. Chem. 2013, 69, 735-753. https://doi.org/10.1016/j.ejmech.2013.08.053

4. Kaur, K.; Kumar, V.; Gupta, G.K. Trifluoromethylpyrazoles as anti-inflammatory and antibacterial agents: A review, J. Fluorine Chem. 2015, 178, 306-326. https://doi.org/10.1016/j.jfluchem.2015.08.015 
5. Kumar, V.; Aggarwal, R.; Tyagi, P.; Singh, S.P. Synthesis and antibacterial activity of some new 1-heteroaryl-5-amino-4-phenyl-3-trifluoromethyl-pyrazoles, Eur. J. Med. Chem. 2005, 40, 922-927. https://doi.org/10.1016/j.ejmech.2005.03.021

6. Aggarwal, R.; Kumar, V.; Tyagi, P.; Singh, S.P. Synthesis and antibacterial activity of new 1-heteroaryl-5-amino-3-H/methyl-4-phenylpyrazoles, Bioorg. Med. Chem. 2006, 14, 1785-1791. https://doi.org/10.1016/j.bmc.2005.10.026

7. Penning, T.D.; Talley, J.J.; Bertenshaw, S.R.; Carter, J.S.; Collins, P.W.; Docter, S.; Graneto, M.J.; Lee, L.F.; Malecha, J.W.; Miyashiro, J.M.; Rogers, R.S.; Rogier, D.J.; Yu, S.S.; Anderson, G.D.; Burton, E.G.; Cogburn, J.N.; Gregory, S.A.; Koboldt, C.M.; Perkins, W.E.; Siebert, K.; Veenhuizen, A.M.; Zhang, Y.Y.; Isakson, P.C. Synthesis and biological evaluation of the 1,5-diarylpyrazole class of cyclooxygenase-2 inhibitors: identification of 4-[5-(4-methylphenyl)-3-(trifluoromethyl)-1H-pyrazol-1-yl]benzenesulfonamide (SC-58635, celecoxib) J. Med Chem. 1997, 40, 1347-1365. https://doi.org/10.1021/jm960803q

8. Reid, J.C.; Calvin, M.J.Am. New $\beta$-diketones containing the trifluoromethyl Group. Chem Soc. 1950, 72, 2948-2952.

9. Pashkevich, K.I.; Bobrov, M.B.; Aizikovich, A.Y.; Rudyaka, M.N. Izv. Akad. Nauk. SSSR, Ser Khim. 1986, 2157.

10. Tegginamath, G.; Kamble, R.R.; Kattimani, P.P.; Margankop, S.B. Synthesis of 3-aryl-4-(\{2-[4-(6-substitutedcoumarin-3-yl)-1,3-thiazol-2-yl]hydrazinylidene\}methyl/ethyl)-sydnones using silica sulfuric acid and their antidiabetic, DNA cleavage activity. Arabian J. Chem. 2016, 9, S306-S312. https://doi.org/10.1016/j.arabjc.2011.04.006

11. Vangrevelingie, E.; Zimmermann, K.; Schopfer, J.; Portmann, R.; Fabro, D.; Furet, P. Discovery of a potent and selective protein kinase CK2 inhibitor by high-throughput docking. J Med Chem. 2003, 46, 2656-2662. https://doi.org/10.1021/jm030827e

12. Rollinger J.M.; Steindl, T.M.; Schuser, D.; Kirchmair, J.; Anrain, K.; Ellmerer, E.P.; Langer, T.; Stupnez, H.; Wutzler, P.; Schnidtke, M. Structure-Based virtual screening for the discovery of natural inhibitors for human rhinovirus coat protein. J Med Chem. 2008, 51, 842-851. https://doi.org/10.1021/jm701494b

13. Trott, O.; Olson, A.J. AutoDock Vina: improving the speed and accuracy of docking with a new scoring function, efficient optimization, and multithreading. J. Comput. Chem. 2010, 31, 455-461. https://doi.org/10.1002/jcc.21334.

14. Singh, S.P.; Kumar, V.; Aggarwal, R.; Elguero, J. The reaction of aryl and heteroarylhydrazines with aryl-trifluoromethyl- $\beta$-Diketones, J. Heterocycl. Chem. 2006, 43, 1003-1014. https://doi.org/10.1002/jhet.5570430428 